\title{
Diet and feeding habits of Saurida tumbil (Bloch, 1795) from northern Kerala, south-west coast of India
}

\author{
P. P. MANOJKUMAR* AND P. P. PAVITHRAN \\ Calicut Research Centre of ICAR-Central Marine Fisheries Research Institute, Kozhikode - 673 005, Kerala, India \\ Tuticorin Research Centre of ICAR-Central Marine Fisheries Research Institute, Thoothukudi - 682001 \\ Tamil Nadu, India \\ e-mail:manojppin@yahoo.com
}

\begin{abstract}
Composition of the diet of greater lizardfish Saurida tumbil (Bloch, 1795), caught from northern Kerala, south-west coast of India was studied and described. The stomachs of 1981 specimens were collected between January, 2012 and June, 2014. Analysis of stomach contents based on index of relative importance (IRI) revealed that this species is exclusively piscivorous. Contrary to other benthic predators of the study area, it mainly feeds on pelagic and demersal fishes $(I R I=63.2)$, molluscs $(I R I=17.86)$, crustaceans $(I R I=18.33)$ and other miscellaneous items $(I R I=2.54)$. The diet of $S$. tumbil were found to be related to the seasonal availability of resources, occurrence of juveniles of certain species and on the migration of fishes from nearby places to the study area. Significant changes in prey items were observed between predator length groups, but a positive, significant relationship was recorded between prey size and predator size $(p<0.05)$. Statistical analysis indicated a uniform representation of different diets in the stomach. Maximum similarity in diet between different food items was found in April and November.
\end{abstract}

Keywords: Diet, Feeding habits, Index of relative importance, Lizard fish, Saurida tumbil

\section{Introduction}

Lizardfishes (family: Synodontidae) occupy an important place as a demersal fishery resource worldwide. The group includes 70 species under four genera. Lizardfishes in India are represented by 3 genera, namely Saurida, Synodus and Trachinocephalus comprising about 20 species. Among them, the genus Saurida is commercially important and is represented by about 10 species. Of these, two species namely, Saurida tumbil (Bloch, 1795) and Saurida undosquamis (Richardson, 1848) are commercially important having high flesh content and good flavour. Kerala contributed about $1446 \mathrm{t}$ of lizardfishes annually forming $7.72 \%$ of the all India lizardfish catch during the 10 year period of 2005-2014. Studies on lizardfishes reported earlier in Indian waters include that of Kuthalingam (1959), Rao (1983; 1984), Nair et al. (1992), Sivakami et al., (2003), Rao (1981), Dighe (1977) and Manojkumar and Sivakami (2005). The present paper details the dietary composition and feeding habits of $S$. tumbil from Malabar coast of Kerala.

\section{Materials and methods}

Samples of S. tumbil collected randomly at weekly intervals during 2012 - 2014 from the fish landings at Puthiappa, Beypore and Chombala (Fig.1) were used for

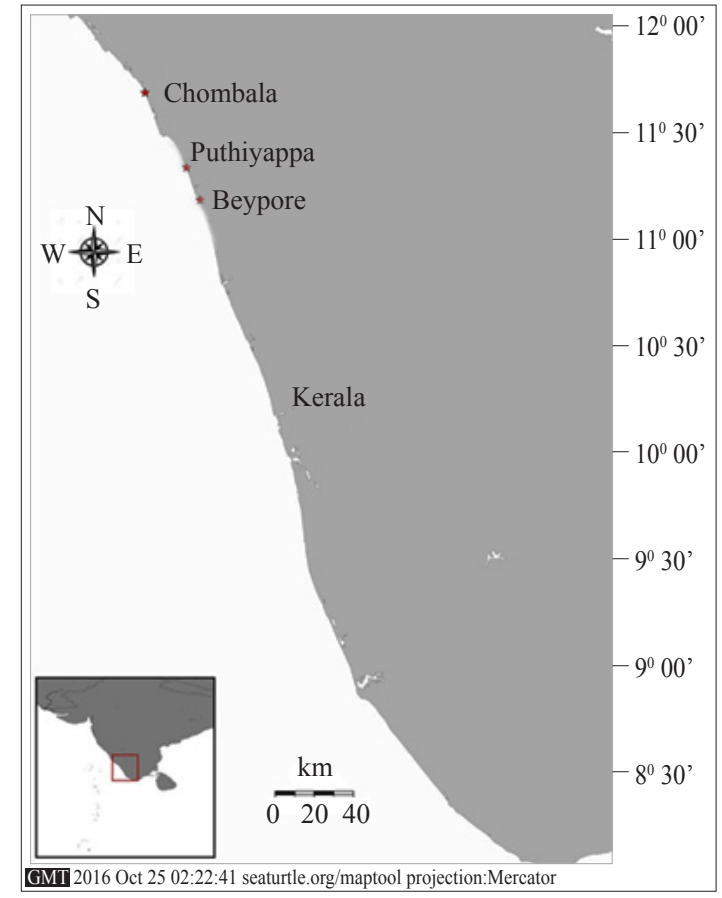

Fig.1. Map showing study area

the study. A total of 1981 specimens in the length range of 102-510 mm was analysed. Data on total length and maturity stage of the fish were recorded and the stomach 
contents were analysed using the index of relative importance (IRI) (Pinkas et al., 1971). Intensity of feeding was determined based on the degree of distension of the stomach due to feeding and the amount of food items available in the stomach. The stomachs were accordingly classified as gorged, full, 3/4, 1/2, 1/4 full, trace and empty. Data thus collected during the study period were pooled and classified as poorly fed (empty and trace), moderately fed $(1 / 4$ and $1 / 2$ full $)$ and heavily fed ( $3 / 4$ full, full and gorged). Since no difference in the food and feeding habits of both the sexes was noticed, data of both sexes were combined. The cumulative monthwise dominance plot and cluster analyses were done using PRIMER 6 software.

\section{Results}

Results showed that $S$. tumbil feeds on 36 food items which are classified into four general categories namely, fishes, molluscs, crustaceans and miscellaneous items (Table 1).

\section{Food items}

Fishes: Analysis of the annual stomach contents of S. tumbil during the years 2012-14 revealed that the diet was essentially similar during this period. Species of fish identified in the stomachs were: Nemipterus japonicus, Nemipterus randalli, Decapterus russelli, Cynoglossuss macrostomus, Stolephorus spp., Bregmaceros mcclellandi, horse mackerel, Epinephelus diacanthus, other flat fishes, Lactarius lactarius, Rastrelliger kanagurta, S. tumbil, S. undosquamis, fish larvae, Sardinella longiceps, silver bellies (Leiognathus bindus and Secutor insidiator), other sardines, flatheads (Platycephalus spp.), sciaenids (Johnieops spp.), goatfishes (Upeneus spp.), eel (Gymnothorax spp.) and Apogon spp. The average annual composition of all fishes for the period had an IRI value of 63.20. Fishes formed the dominant dietary element of $S$. tumbil which was observed throughout the year. The IRI values for fishes were highest during August (94.41) and lowest in December (35.26). $N$. japonicus was the dominant food item found in the stomach of $S$. tumbil with IRI value ranging from 2.29 (February) to 74.67 (August) (with mean IRI of 21.73). R. kanagurta formed the second dominant food item with an IRI value of 9.04 and monthly IRI value ranged between 0.44 (April) and 47.6 (November). The third dominant fish food item was D. russelli with IRI value of 0.42 (March) - 24.33 (October). Horsemackerel was another dominant food item and its IRI values were between 1.39 (March) and 43.31 (April). Stolephorus spp. were represented by Stolephorus devisi and S. commersonii and the IRI values ranged between 0.11 (February) and 47.05 (June). Other fishes found in the stomach were $N$. randalli $($ IRI $=2.47)$, flatheads $($ IRI $=1.98)$, eels $($ IRI $=1.73)$,
C. macrostomus (IRI $=0.92)$, S. tumbil $(\mathrm{IRI}=0.71)$, silverbellies $(\mathrm{IRI}=0.40), \mathrm{B}$. mcclellandii $(\mathrm{IRI}=0.24)$, sciaenids $(\mathrm{IRI}=0.31)$, goatfishes $(\mathrm{IRI}=0.25)$, fish larvae $(\mathrm{IRI}=0.21)$, other sardines $(\mathrm{IRI}=0.04)$, L. lactarius $(\mathrm{IRI}=0.03)$, other flatfishes $(\mathrm{IRI}=0.01), E$. diacanthus $(\mathrm{IRI}=0.01)$ and Apogon spp. $(\mathrm{IRI}=0.02)$. Juvenile fishes contributed to the diet for a greater part of the year. They were maximum in November $(I R I=75.21)$ and minimum in April (IRI = 24.79).

Crustaceans: The second most important prey category was crustaceans $(\mathrm{IRI}=18.33)$. Acetes spp. $(\mathrm{IRI}=9.11)$, Fenneropenaeus indicus (IRI =9.02), mysids (IRI = 0.18), Metapenaeus stridulans (IRI $=0.01)$, Parapeneaopsis stylifera $(\mathrm{IRI}=0.01)$ and crabs $(\mathrm{IRI}=0.01)$ being the most important crustacean diet items. Acetes spp., was the chief crustacean component found in the stomach with a peak occurrence during December $($ IRI $=20.98)$ and minimum in March (IRI = 7.16). F. indicus was present during nine months with peak occurrence in April (IRI $=19.57)$ and minimum in November (IRI $=0.33$ ). Mysids were represented by Mesopodopsis orientalis, M. zeylanica, Rhopalophthalmus indicus and Kochimysis pillaii with peak occurrence in June. Thalamitta spp., a small sized crab was present in the food with peak occurrence during May and August. Negligible quantities of M. stridulans were observed with average IRI of 0.11 .

Molluscs: Molluscs represented by squids viz., Uroteuthis (Photololigo) duvaucelii, U.(P.) edulis and U.(P.) singhalensis; cuttlefishes (juveniles of Sepia pharaonis and Sepiella inermis) and octopus (Amphioctopus membranaceus and $A$. aegina) were present in the diet almost throughout the year and the average IRI for this item was 7.86. The highest IRI value was observed in February (38.1) and minimum in June (2.47). The IRI values for squids, cuttlefishes and octopus were 19.23, 0.09 and 0.18 respectively.

Miscellaneous items: Miscellaneous food items observed occasionally in the stomach were medusa, detritus, jellyfish, salpa and rope bits and the average IRI value of this group was 2.54. The highest IRI value was observed in May (8.13) and lowest in January (0.03). As their volumes were low, they were considered as secondary inclusions in the diet. The IRI values of jellyfish, salpa, medusae and nereis worms were $0.03,0.02,2.47$ and 0.02 respectively.

\section{Seasonal variations in feeding}

Fishes occupied an important place throughout the year and their peak occurrence was observed during monsoon period (IRI $=68.97)$, followed by post-monsoon months (IRI $=62.53)$ and pre-monsoon period $($ IRI $=58.13$ ) (Fig. 2). Among fishes, threadfin breams represented by $N$. japonicus and $N$. randalli 
Table 1. Index of relative importance (IRI) of different food items in Saurida tumbil along northern Kerala during 2002-14

\begin{tabular}{|c|c|c|c|c|c|c|c|c|c|c|c|c|c|}
\hline Prey items & Jan & Feb & Mar & Apr & May & Jun & Jul & Aug & Sep & Oct & Nov & Dec & Annual \\
\hline \multicolumn{14}{|l|}{ Fishes } \\
\hline Eels & 8.83 & - & 3.95 & 2.1 & - & - & - & - & 2.61 & - & 0.09 & 0.19 & 1.73 \\
\hline Apogon spp. & - & - & 0.21 & - & - & & - & - & - & - & - & - & 0.02 \\
\hline C. macrostomus & 1 & 3.56 & 1.49 & 1.46 & 0.46 & - & - & - & 0.33 & 2.07 & 0.23 & - & 0.92 \\
\hline D. russelli & 13.52 & 4.4 & 0.42 & 0.92 & 2.92 & 3.63 & - & 14.95 & 3.07 & 24.33 & 5.37 & 19.59 & 8.83 \\
\hline Horsemackerel & - & 25.14 & 1.39 & 43.31 & 7.2 & - & - & - & 2.39 & 6.06 & 0 & 4.69 & 7.65 \\
\hline E. diacanthus & - & - & - & - & - & - & - & 0.10 & - & - & - & - & 0.01 \\
\hline Other flat fishes & - & - & - & - & - & - & - & 0.10 & - & - & - & - & 0.01 \\
\hline L. lactarius & - & 0.14 & - & - & - & - & - & - & 0.15 & - & - & - & 0.03 \\
\hline R. kanagurta & 13.05 & 4.08 & 10.6 & 0.44 & 1.06 & - & - & - & 6.31 & 3.19 & 47.6 & 1.46 & 9.04 \\
\hline Saurida tumbil & - & 0 & 0.95 & 0 & 5.68 & - & - & 0.22 & 1.71 & - & - & - & 0.71 \\
\hline Stolephorus spp. & - & 0.11 & 12.34 & 0 & 3.15 & 47.05 & - & 4.21 & 12.45 & - & 0.22 & - & 6.62 \\
\hline S. undosquamis & - & - & - & - & - & - & - & 0.17 & 0.07 & - & - & - & 0.02 \\
\hline N. randalli & - & - & - & - & - & - & - & 0 & 8.43 & 3.27 & 12.59 & 0.85 & 2.47 \\
\hline Fish larvae & - & 2.19 & 0 & 0.12 & - & - & - & - & - & - & - & 0.18 & 0.21 \\
\hline$N$. japonicus & 40.72 & 2.29 & 28.96 & 13.64 & 26.06 & 22.46 & - & 74.67 & 8.47 & 19.42 & 4.13 & 3.71 & 21.71 \\
\hline S. longiceps & - & - & - & 0.02 & 0 & - & - & - & - & - & - & - & 0.01 \\
\hline Silverbellies & - & - & - & 0.56 & 2.66 & - & - & - & - & - & - & 1.15 & 0.40 \\
\hline B. mcclellandi & - & - & - & - & 0.56 & 2.26 & - & - & - & - & - & - & 0.24 \\
\hline Other sardines & - & - & 0.51 & - & - & - & - & - & - & - & - & - & 0.04 \\
\hline Flatheads & - & 2.55 & 0.18 & 6.8 & 4.79 & - & - & - & - & 1.93 & 3.92 & 1.71 & 1.98 \\
\hline Sciaenids & - & - & - & - & - & - & - & - & - & - & 1.05 & 1.74 & 0.31 \\
\hline Goatfish & - & - & - & - & 3.03 & - & - & - & - & - & - & - & 0.25 \\
\hline Fishes total & 77.13 & 44.46 & 61 & 69.37 & 57.58 & 75.4 & - & 94.41 & 45.8 & 60.26 & 75.21 & 35.26 & 63.20 \\
\hline \multicolumn{14}{|l|}{ Crustaceans } \\
\hline Acetes spp. & - & - & 7.16 & - & 7.34 & - & - & - & 17.07 & 15.66 & 16.59 & 20.98 & 9.11 \\
\hline Crabs & - & - & - & - & 2.51 & - & - & 0.05 & - & - & - & - & 0.01 \\
\hline M. stridulans & - & - & - & - & - & - & - & - & - & - & - & 0.11 & 0.01 \\
\hline P. stylifera & - & - & - & - & - & - & - & - & - & - & - & 0.07 & 0.01 \\
\hline F. indicus & - & 16.39 & 3.2 & 19.57 & 8 & 10.16 & - & - & 19.17 & 5.27 & 0.33 & 7.04 & 9.02 \\
\hline Mysids & - & - & - & - & - & 5.04 & - & - & - & - & - & - & 0.18 \\
\hline Crustaceans total & - & 16.39 & 10.36 & 19.57 & 17.84 & 10.16 & - & 0.05 & 36.24 & 20.94 & 16.93 & 28.2 & 18.34 \\
\hline \multicolumn{14}{|l|}{ Molluscs } \\
\hline Cuttlefishes & - & - & - & 0.61 & - & - & - & - & - & - & - & 0.23 & 0.09 \\
\hline Squids & 22.83 & 38.1 & 25.74 & 3.51 & 16.45 & 2.47 & - & 5.24 & 17.34 & 18.59 & 4.59 & 35.79 & 19.23 \\
\hline Octopus & - & - & - & 1.68 & - & - & - & - & - & - & - & - & 0.18 \\
\hline Molluscs total & 22.83 & 38.1 & 25.74 & 5.81 & 16.45 & 2.47 & - & 5.24 & 17.35 & 18.59 & 4.59 & 36.01 & 17.86 \\
\hline \multicolumn{14}{|c|}{ Miscellaneous items } \\
\hline Medusa & 0.03 & 0.94 & 2.89 & 4.92 & 8.13 & 6.93 & - & 0.3 & 0.41 & 0.15 & 3.27 & 0.43 & 2.47 \\
\hline Salpa & - & - & - & 0.29 & - & - & - & - & - & - & - & - & 0.02 \\
\hline Jelly fish & - & - & - & - & - & - & - & - & 0.19 & 0.06 & - & 0.04 & 0.03 \\
\hline Neeris & - & 0.11 & - & 0.04 & - & - & - & - & - & - & - & 0.07 & 0.02 \\
\hline Detritus & - & - & - & - & - & - & - & - & 0.01 & - & - & 0 & 0.00 \\
\hline Others total & 0.03 & 1.05 & 2.89 & 5.25 & 8.13 & 6.93 & - & 0.3 & 0.61 & 0.21 & 3.27 & 0.54 & 2.54 \\
\hline
\end{tabular}

recorded IRI values of 21.73 and 2.47 respectively. IRI of $N$. japonicus was high during monsoon period (31.25), followed by pre-monsoon (17.74) and postmonsoon months (16.19). In the case of $N$. randalli, highest IRI was recorded during post-monsoon months (4.48), followed by monsoon months (2.93), but in pre-monsoon months $N$. randalli was absent in the stomach of $S$. tumbil. D. russelli was negligible in the stomach during pre-monsoon months (IRI $=2.87$ ), which gradually increased to 11.49 during monsoon season and further to 12.85 during post-monsoon months (IRI $=12.83$ ). Presence of horsemackerel was more during pre-monsoon months (IRI $=19.26$ ), which further declined to 2.1 in monsoon and further to 1.56 during post-monsoon months. Occurrence of $R$. kanagurta in the diet was more during post-monsoon months with an IRI value of 20.7 and 


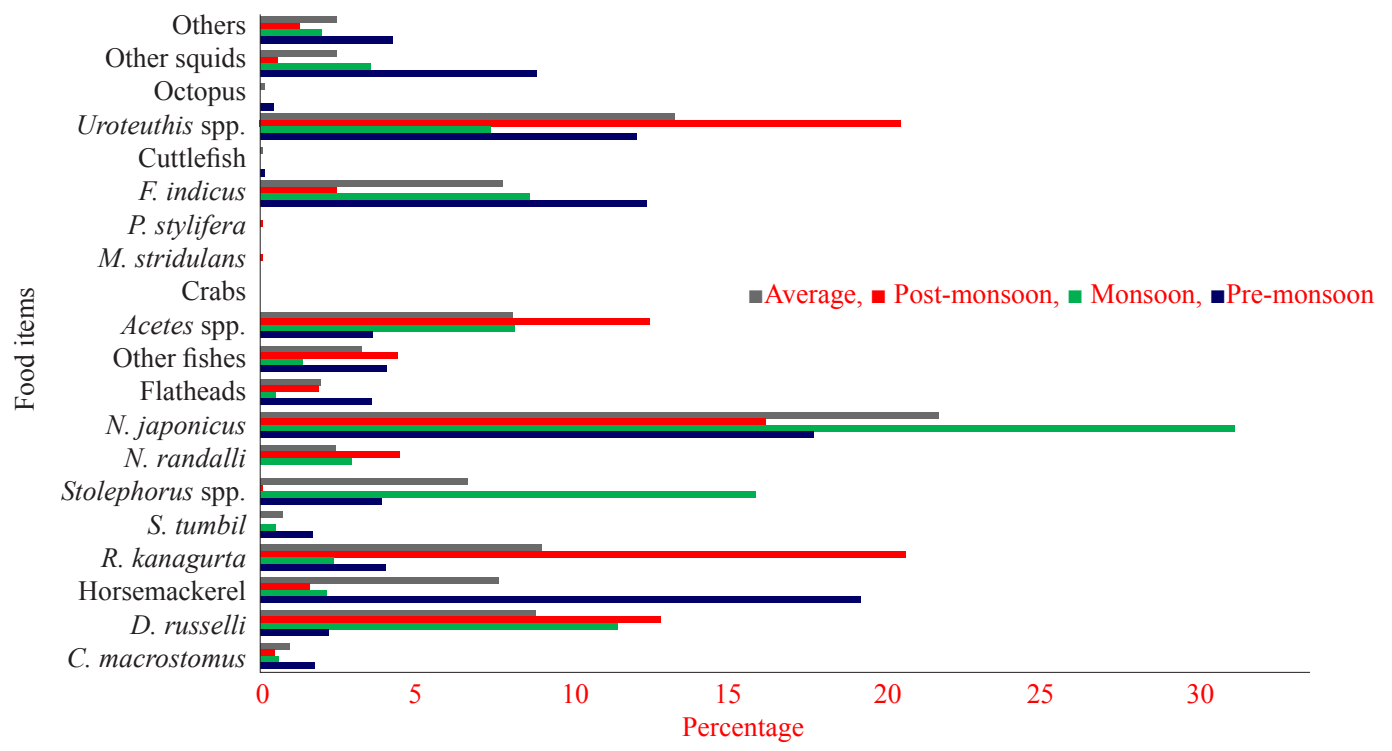

Fig. 2. Seasonwise IRI of different food items in S. tumbil

during pre-monsoon and monsoon months the IRI values were negligible. Stolephorus spp. was highest in the guts during monsoon period with an IRI value of 15.87 and during pre-monsoon period the IRI was 3.90 and it was negligible during post-monsoon (IRI $=0.07$ ). Presence of other fishes in the diet was more during post-monsoon $(\mathrm{IRI}=4.41)$ and pre-monsoon period (4.03). In general IRI value of fishes in $S$. tumbil was higher during monsoon and post-monsoon months.

Among crustaceans, highest IRI was recorded during monsoon (16.04) and pre-monsoon period (16.85), which declined to 15.04 during post-monsoon months. Occurrence of Acetes spp. in the diet was high in post-monsoon period (IRI =12.52). F. indicus dominated with IRI value of 12.42 , its presence gradually declined in monsoon months (IRI $=8.65)$ and further during the post-monsoon period (IRI $=2.46$ ). Presence of molluscs in the diet was more during pre-monsoon and post-monsoon months.

Dominance plot was constructed on the data sets to find out the diet components at different months and the curve for December which lies on the lower side, extends further and rises slowly due to the uniform composition of different diets. The curve for August shows higher dominance of fishes in the stomach of $S$. tumbil (Fig. 3).

Cluster analysis revealed grouping of dietary components over the months in S. tumbil. Cluster analysis did not reveal any definite pattern over the months due to its voracious feeding nature. The highest similarity of 98.95\% was found between April and November followed by $93.15 \%$ in February and November (Fig. 4).

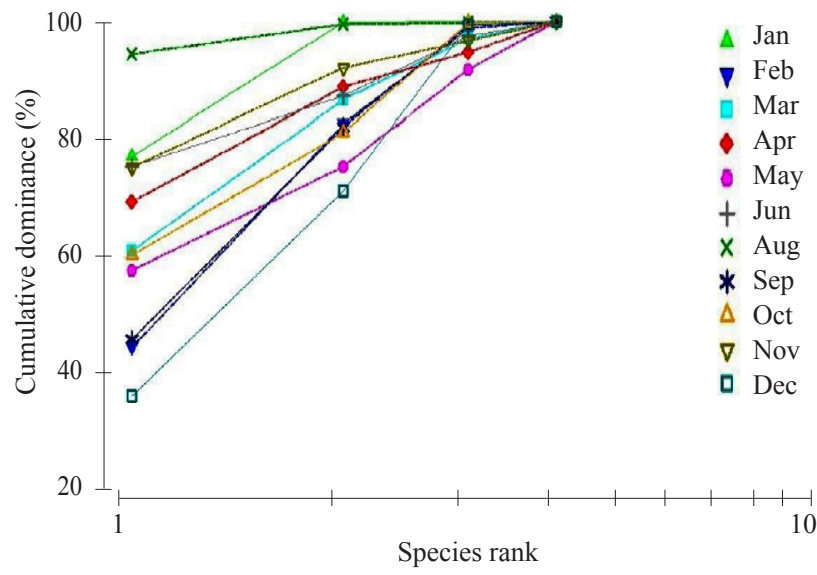

Fig. 3. Plot of monthwise cumulative dominance for S. tumbil from northern Kerala

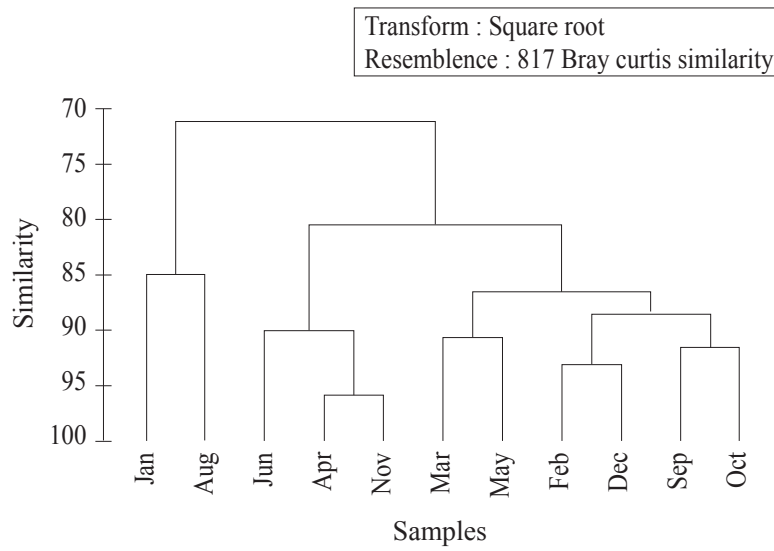

Fig. 4. Dendrogram based on cluster analysis of monthwise diet assemblege of $S$. tumbil from northem Kerala 


\section{Food in relation to size}

Analysis of the food items in relation to size of the fish species studied indicated that fishes were preferred by all length groups and the IRI of fishes of most of the length groups were higher (Fig. 5). Crustaceans were the second dominant food preferred by the fish, particularly they were the most preferred food item by the juveniles. There was gradual preference for fish items as the size of fish increased. Between 290-359 mm length group, preference for fishes as well as crustaceans were almost equal. Juveniles of Stolephorus spp. were the only item that dominated the food of young fish up to $149 \mathrm{~mm}$. Other teleost fishes started to appear in the diet of $S$. tumbil from $150 \mathrm{~mm}$ size and above. Juveniles of B. mcclellandi as well as threadfin breams appeared in the gut from $140 \mathrm{~mm}$ onwards.

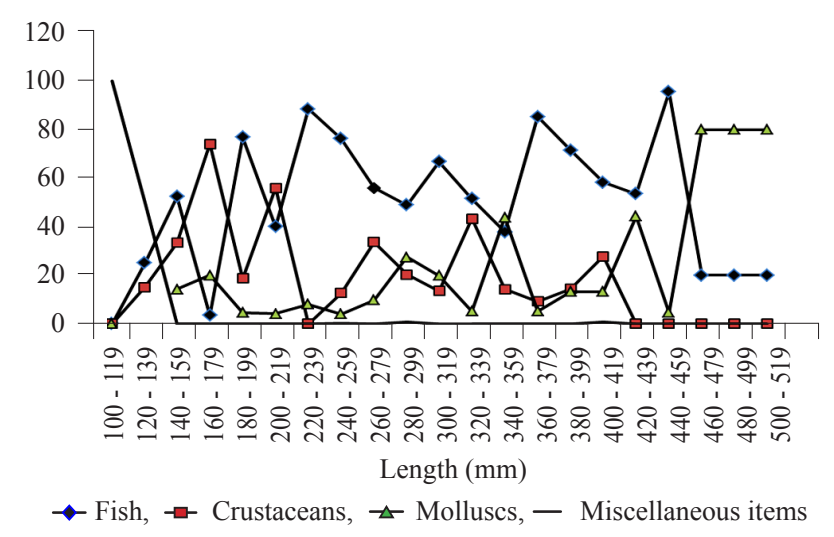

Fig. 5. Lengthwise food composition of Saurida tumbil

Presence of crustaceans like penaeid shrimps, mysids, crabs, Acetes spp. and stomatopods were observed in the diet upto $359 \mathrm{~mm}$ size. Mysids were present only in juvenile and subadult fishes. Young ones of squids, cuttlefishes and octopus were occasionally present in the diet contents of fish below $150 \mathrm{~mm}$. Juveniles of squids were present in the stomach from $140 \mathrm{~mm}$ onwards and their presence continued upto $509 \mathrm{~mm}$. Cuttlefishes formed prominent food items when the fishes were above $230 \mathrm{~mm}$. Miscellaneous items were present in the fishes of all size groups in small quantities.

\section{Feeding intensity}

Poorly fed fishes were observed during all the months and on an average it formed $56.39 \%$ (Fig. 6.) Highest percentage of fishes with empty stomachs indicates that the intensity of feeding in different months has no regular periodicity. Fishes with heavily fed stomachs were observed more during January, October, November and December months which indicates that the feeding intensity was high during these months.

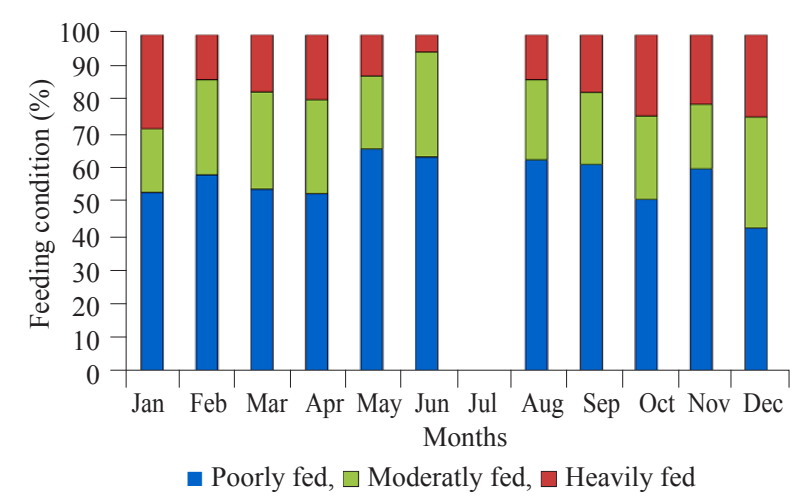

Fig. 6. Monthly feeding condition of S. tumbil

Feeding condition in relation to different maturity stages indicated that intensity of feeding was higher in immature (89.47\%), maturing (55.25\%) and spent fishes (30.81\%) (Fig. 7). Moderately fed stomach fluctuated between $9.78 \%$ in immature fishes to $24.17 \%$ in maturing fishes. Poorly fed fishes were more in mature fishes $(60.39 \%)$ and least in immature fishes $(0.75 \%)$.

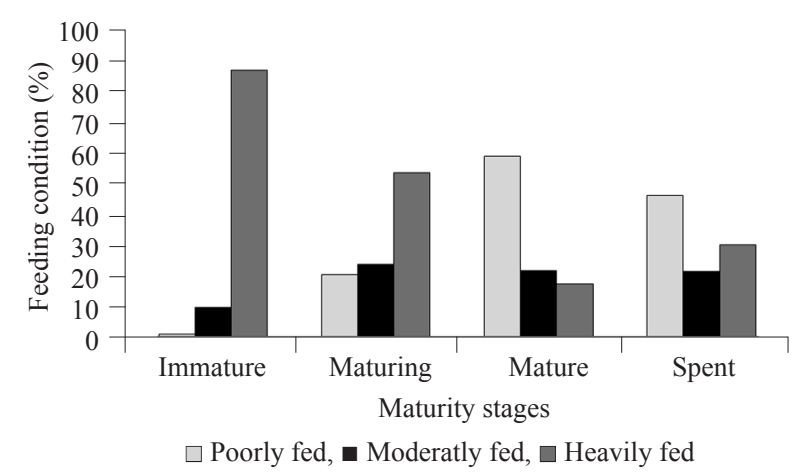

Fig. 7. Feeding condition of $S$. tumbil in relation to different stages of maturity

\section{Discussion}

Results of the present study shows that S. tumbil feeds mainly on fishes, crustaceans and cephalopods. Food of $S$. tumbil comprised of fishes, molluscs and crustaceans in the East China Sea (Yamada et al., 1966). Tiews et al. (1972) reported that fishes are the favourite food of $S$. tumbil in the Philippine waters. The main food of S. tumbil along the Oman coast was fishes, cephalopods and crustaceans (Budnichenko, 1974). While S. tumbil from the Bombay coast fed mainly on fishes, molluscs were next important and crustaceans the third (Dighe, 1977). The diet of $S$. tumbil, from Bay of Bengal comprised of fishes and the rest were Loligo sp. and crustaceans (Rao, 1981). The present observations have shown that threadfin breams, $R$. kanagurta, D. russelli, Stolephorus spp. and $U$.(P.) duvaucelii as the most preferred food item of $S$. tumbil. This is evident from their dominance in the food in 
all months. The next favoured diet seemed to be shrimps, Acetes spp., crabs and mysids. However, Kuthalingam (1959) recorded shrimps as the major food item of S. tumbil along with teleostean larvae as well as adults, small quantity of copepods, cirripede larvae, decapod larvae and Sagitta spp. from Madras waters. In the present study, it was seen that $N$. japonicus, $R$. kanagurta, D. russelli, horsemackerel and Stolephorus spp., formed the dominant diet of $S$. tumbil and their dominance continued even after the fish has grown to large size. From this it is clear that the above fishes are the preferred diet of $S$. tumbil as observed from different regions (Rao, 1964, Yamada et al., 1966, Tiews et al., 1972 and Dighe, 1977). According to Yamada et al. (1966), juveniles of $S$. tumbil fed mainly on shrimps and juvenile jackmackerel. As the fish grows, they feed on anchovy and cuttlefish and the larger fish feed on small jackmackerel, hairtail and cardinal fish. Budnichenko (1974) also observed variation in the diet composition among different size groups of $S$. tumbil. He observed that the food of small individuals consisted predominantly of Bregmacerotidae, Callionymidae, Champsodontidae, Trichiuridae, Squilla sp. and Loligo sp. and that the larger fishes feed on Loligo spp., Clupeidae, Carangidae, Sparidae and Nemipteridae. Dighe (1977) reported that while $S$. tumbil in all stages of growth feed on fishes, crustaceans were consumed more by smaller fish and molluscs by those in advanced stages of growth. Rao (1981) reported that the food of S. tumbil of less than $160 \mathrm{~mm}$ were composed of small fish mainly Stolephorus spp., Leiognathus spp. and Sardinella spp. Large fishes fed more on large size fishes like Trichiurus spp., Leiognathus spp., Upeneus spp., $R$. kanagurta and carangids. The volume of crustaceans and cephalopods in the diet was more in the $16-30 \mathrm{~cm}$ size group than in the $31-45 \mathrm{~cm}$ size group. In the 160$300 \mathrm{~mm}$ size group, fish item increased appreciably and cephalopod diet was steady, whereas the shrimp intake reduced to low levels. The percentage of intake of cephalopod was high in fish up to $300 \mathrm{~mm}$ and low in $S$. tumbil $>300 \mathrm{~mm}$. In the present observation, the proportion of fish diet was high in fishes up to $259 \mathrm{~mm}$ and with growth, fish diet decreased while cephalopod diet increased. Bregmaceros sp. constituted the principal diet up to $110-119 \mathrm{~mm}$ and above this length, Stolephorus spp. increased. Low feeding activity during the spawning season was observed in $S$. tumbil from Bombay waters (Dighe, 1977) and from the north-western part of Bay of Bengal (Rao, 1981). In contrast, high feeding intensity was recorded in both sexes of $S$. tumbil during the spawning period (Yamada et al., 1966; Qiyong and Ganlin, 1986). However, Tiews et al. (1972) could not find any seasonal variation in feeding intensity. The present study has shown that feeding intensity was relatively higher in immature and spent fishes.
Although items like shrimps, carangids, soles and sciaenids were recorded in good proportion in trawl catches along with Saurida spp., they were poorly represented in the stomachs of Saurida spp. Rao (1981) observed Leiognathus bindus as the major food of $S$. tumbil on the east coast, but in the west coast, $S$. tumbil does not prefer Leiognathus spp., though they are available in the environment in good quantity. The cannibalistic nature of Saurida spp. as reported by Tews et al. (1972); Yamada et al. (1966); Qiyong and Ganlin (1986); Wu (1984) and Rao (1981), was also observed in the present study. But the presence of pelagic fishes in the stomach of $S$. tumbil led Budnichenko (1974) to conclude that S. tumbil is capable of pursuing their prey actively for more distance and even making short vertical migrations. However, Hayashi (1983) remarked that lizardfish resorts to change of feeding behaviour between sit and wait feeding on benthic prey and mobile searching behaviour for pelagic prey based on the prey resource in the environment. The present observation of Saurida tumbil, feeding mainly on pelagic prey in the area shows that they indulge in more mobile searching behaviour than of sit and wait mode for benthic prey.

\section{Acknowledgements}

The authors are thankful to Dr. A. Gpalakrishanan, Director, ICAR-CMFRI, Kochi and Dr. P. U. Zacharia, Principal Scientist and Head, Demersal Fisheries Division, ICAR-CMFRI, Kochi for their encouragements.

\section{References}

Budnichenko, V. A. 1974. The feeding of Saurida undosquamis and Saurida tumbil (Synodontidae) along the Oman Coast. J. Ichthyol., 14(2): 267-272.

Dighe, J. P. 1977. A study of lizardfish Saurida tumbil (Bloch). Ph. D. Thesis, University of Bombay, $161 \mathrm{pp}$.

Hayashi, T. 1983. What insights can be gained from stomach contents? Essay on the feeding strategy of the lizardfish from informations gathered from the stomach contents. J. Fac. App. Biol. Sci. Hiroshima Univ., 22: 271-302.

Kuthalingam, M. D. K. 1959. Saurida tumbil (Bloch): development and feeding habits. J. Zool. Soc. India, 11(2): 116-124.

Manojkumar, P. P. and Sivakami, S. 2005 Fishery of lizardfishes off Veraval with stock assessment of Saurida tumbil (Bloch). Indian J. Fish., 52(3): p. 323-329.

Nair, K. V. Somasekharan., Vinay, D. Deshmukh and Raje, S. G. 1992. Present status of exploitation of fish and shelfish resources: Lizardfishes. Bull. Cent. Mar. Res. Inst., 45: 182-196.

Pinkas, L., Oliphant, M. S. and Iverson, I. L. K. 1971. Food habits of albacore, bluefin tuna and bonito in Californian 
waters. California Department of Fisheries and Game, Fisheries Bulletin, 152: 1-105.

Qiyong, Z. and Y. Ganlin, 1986. Study on feeding habits of lizardfishes in South Fujian and Taiwan Bank fishing ground. J. Fish. China, 10(2): 213-222.

Rao, K. V. S. 1964. On the occurrence of Saurida undosquamis (Richardson) off Vishakapatnam. J. Mar. BioI. Ass. India, 6(2): 265-267.

Rao, K. V. S. 1981. Food and feeding of lizardfishes (Saurida spp.) from north western part of Bay of Bengal. Indian J. Fish., 28 (1 \& 2): 47-64.

Rao, K. V. S. 1983. Maturation and spawning of lizardfishes (Saurida spp.) from north-western part of Bay of Bengal. Indian J. Fish., 30: 27-45.
Rao, K. V. S. 1984. Age and growth of lizardfishes (Saurida spp.) from the north-western Bay of Bengal. Indian $J$. Fish., 31(1): 19-30.

Sivakami, S., Vivekanandan, E., Raje, S. G. and Kizhakudan, Shoba Joe 2003. Lizardfishes, pomfrets and bullseye. In: Mohan Joseph, M. and Jayapraksh, A. A. (Eds.), Status of exploited marine fishery resources of India. Central Marine Fisheires Research Institute, Kochi, p. 141-157.

Tiews, K. A. Mines and Ronquillo, L. A. 1972. On the biology of Saurida tumbil (Bloch, 1801), Family synodontidae in Philippine waters. Proc. Indo-Pacific Fish. Coun., 13(III): 100-120.

Yamada, U., Tagawa, M. and Mako, H. 1966. On the feeding activity of the lizardfish Saurida tumbil in the East China Sea. Bull. Seikai Reg.Fish Res. Lab., 34: 11-25.

Wu, R. S. S. 1984. The feeding habits of seven demersal fish species in a sub-tropical estuary. Asian Mar. Biol., 1: 17-26.

Date of Receipt ～: 24.07.2016

Date of Acceptance : 29.10 .2016 